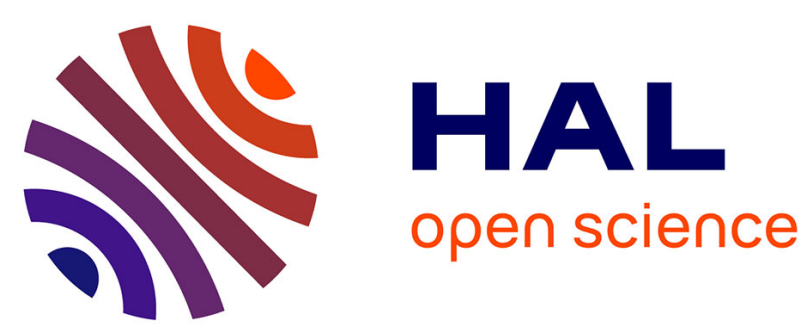

\title{
Towards a Critical Edition of Śankara's 'Longer' Aitareyopaniṣadbhāṣya: a Preliminary Report based on two Cambridge Manuscripts
}

Hugo David

\section{- To cite this version:}

Hugo David. Towards a Critical Edition of Śaṅkara's 'Longer' Aitareyopaniṣadbhāṣya: a Preliminary Report based on two Cambridge Manuscripts. Vergiani, Vincenzo; Cuneo, Daniele; Formigatti, Camillo Alessio. Indic Manuscript Cultures through the Ages, De Gruyter, pp.727-754, 2017, 978-311-054310-0. 10.1515/9783110543100-022 . halshs-02417365

\section{HAL Id: halshs-02417365 \\ https://shs.hal.science/halshs-02417365}

Submitted on 18 Dec 2019

HAL is a multi-disciplinary open access archive for the deposit and dissemination of scientific research documents, whether they are published or not. The documents may come from teaching and research institutions in France or abroad, or from public or private research centers.
L'archive ouverte pluridisciplinaire HAL, est destinée au dépôt et à la diffusion de documents scientifiques de niveau recherche, publiés ou non, émanant des établissements d'enseignement et de recherche français ou étrangers, des laboratoires publics ou privés. 


\title{
Hugo David
}

\section{Towards a Critical Edition of Śañkara's 'Longer' Aitareyopanișadbhāșya: a Preliminary Report based on two Cambridge Manuscripts}

\begin{abstract}
This article presents a fresh assessment of evidence for the existence of Śankkara's 'longer' commentary on the Aitareyopanișad, a sub-section of the Aitareyāranyaka $(\mathrm{Ai} \overline{\mathrm{A}})$. While most printed editions of the Bhāṣya consider that it covers only three adhyāyas of the Āranyaka (AiĀ 2.4-6/7), a much more comprehensive work, bearing on the whole of $\mathrm{Ai} \overline{\mathrm{A}} 2$ and 3, is preserved in manuscripts. In the first part of the article, I argue that the ascription of this 'longer' gloss to Śankara is likely to be justified, building on previous scholarship (A.B. Keith, S.K. Belvalkar) as well as on my own inspection of two manuscripts of the work, newly identified in the Cambridge University Library. Questions are also raised as to the constitution of the Upanișadic canon(s) and the role of commentaries in that process. The second part of the essay provides a comprehensive survey of the material (manuscript and print) available for a first critical edition of this important, though mostly neglected work by the great Vedāntin.
\end{abstract}

\footnotetext{
Research for the present study was started during my stint in Cambridge in 2013-14, for which I benefitted of the generous support of the British Royal Society (Newton International Fellowship), and during which I had the privilege to participate as a regular external collaborator in the Sanskrit Manuscripts Project. I thank the three editors of this volume for facilitating me access to the Cambridge collection in innumerable ways, for sharing their knowledge and expertise of Sanskrit manuscripts, and for allowing me to take part in their endeavour. I am also grateful to Andrew Ollett for providing the copy of a rare document kept in Harvard, to the authorities of the Vadakke Madham Brahmaswam in Thrissur (especially Mr. P. Parameswaran) for opening me the doors to their precious collection of manuscripts, as well as to the following public libraries for their kind cooperation: the Government Oriental Manuscripts Library in Chennai and the Oriental Research Institute and Manuscripts Library in Trivandrum (Kariavattom).
} 


\section{Introduction}

In an article published in 1930 in the Journal of the Bombay Branch of the Royal Asiatic Society, the great Maharashtrian Indologist S.K. Belvalkar drew the attention of scholars to what he called 'an authentic, but unpublished work of Śankkarācārya.' That work was a commentary (Bhāssya) by the great Advaita Vedāntin Śankkara(-ācārya), the author of the Brahmasūtrabhāṣya, on the Aitareyopanișad (AiU), a portion of the Aitareyāranyaka (AiĀ). ${ }^{1}$ Of course, Belvalkar was well aware that a commentary by Śankara on the Upanișad bearing that name had been published as early as 1850 by Edward Röer together with Ānandagiri's gloss (Calcutta, Bibliotheca Indica 6), and again in 1889 by the pandits of the Pune Ānandāśrama with the same sub-commentary (Ānandāśramasaṃskrtagranthāvalih 11). ${ }^{2}$ Yet the work he was describing was very different in extent and character. The AiU is usually thought to be a work in three sections (adhyāya), corresponding to adhyāyas $4-6 / 7^{3}$ of the second book (also called äranyaka) of the $\mathrm{Ai} \overline{\mathrm{A}}$, which is made of five àranyakas altogether. These three adhyāyas are again divided into six sub-sections (khaṇda), hence the name Ätmașațka ('Hexade on the Self') often used to refer to that Upanișad. ${ }^{4}$ Sankkara, in turn, is generally believed to have commented only on these three adhyāyas, 'the Upanișad properly so-called' to use F. Max Müller's phrase. ${ }^{5}$ The three manuscripts discussed by Belvalkar, however, all kept in British and German libraries, ${ }^{6}$ contained

1 As is well-known, the Aitareya-upanișad and ${ }^{\circ}$ aranyaka belong to the Rgveda-tradition, where they are closely related to the Āśvalāyana school. See Renou 1947, 25-26.

2 This is to name only the two most important editions of the text, i.e. those that are surely based on manuscripts. Karl H. Potter, in his Bibliography of Indian Philosophies (online version, last consulted on $10^{\text {th }}$ April, 2017), counts no less than fourteen editions of the AiUBh before 1930, in various Indian scripts (including Tamil, Telugu, etc.), as well as two translations of the text into English and one into Tamil. See https://faculty.washington.edu/kpotter/ckeyt/txt2.htm. The NCC 3 (p. 86) also lists early translations into Bengali (Calcutta, 1881) and Marathi (Pune, 1892). 3 The seventh and last adhyāya of the second āranyaka consists only of a brief invocation (śānti$p \bar{a} t h a)$. Standard editions of the AiĀ give it as a seventh adhyāya, but it is usually found in printed editions of the AiU as a mere appendix to the third section of the Upanișad, not as a separate section. The AiU is therefore generally considered to be a work in three adhyāyas.

4 This is what we find, for instance, in the standard edition of eighteen 'principal' Upanișads by V.P. Limaye and R.D. Vadekar (Pune 1958, 62-67). For an overview of the contents of these three adhyāyas, see Schneider 1963.

5 See Müller 1879, xcvii.

6 For more details on these manuscripts, see below, Section 2. Although Belvalkar refers to three manuscripts in his article (London, Oxford and Berlin), he could examine only one of them, namely the one kept in London. See Belvalkar 1930, 243-244. 
a commentary also ascribed to Śańkara, but on a considerably larger amount of text (partly redundant with the other, shorter, commentary), namely the totality of äranyakas 2 and 3 (eight adhyāyas in total, nine if we include the śāntipātha, on which Śankkara did not comment). A similar work had been briefly described twenty years earlier by A.B. Keith $(1909,11)$ in his monumental study of the Āranyaka, using the same manuscripts. A lithograph of the work, apparently unknown to Keith and Belvalkar, had also been produced in Benares as early as 1884 on the basis of one or several North Indian manuscript(s), of which it scrupulously imitates the layout. ${ }^{7}$ This commentary, which both Keith and Belvalkar considered without hesitation to be the work of Sankara, is two or three times as bulky as the published versions of the AiUBh, and deals with a much wider range of topics, including speculations on elements of the ritual akin to what we find in the first books of the Bṛhadāranyaka ${ }^{\circ}$ and Chāndogyopanișads. For easy reference, I will speak here of the 'shorter' and 'longer' versions of the Aitareyopanișadbhāṣya (AiUBh-S and AiUBh-L).

Given the extreme popularity and historical importance of Śankkara's Upanișadic commentaries, one would expect that Belvalkar's '(re-)discovery' would have attracted massive attention from Indologists and specialists of Vedānta, and would at least have motivated a first publication of the text on the basis of manuscripts in the following years. This is especially true in India, where the article was published in a well-known periodical, and where Śankara is still revered as a major religious figure among Hindus. This, however, was not the case: countless new editions of Śańkara's 'shorter' Bhāssya were printed in the last ninety years - including many reprints of the two $19^{\text {th }}$-century editions mentioned above (when at all they mention their sources) -, but the only version of his 'longer' gloss available in print today remains the 1884 Benares lithograph, the text of which was reprinted by Laxmanshastri Joshi in vol. 2.2 (pp. 525-626) of his Dharmakośa (Upaniṣatkāṇ̣a), published in Wai in 1949. As far as I can see, both publications remained practically unnoticed by scholars of Vedānta.

7 To the best of my knowledge, the only surviving copy of that lithograph, which also includes Ānandagiri's commentary for the Upanișad 'proper,' is found in the Harvard University Library. I was able to secure a scanned copy of this valuable document through the kind efforts of my colleague Andrew Ollett, to whom I am especially grateful. The only other copy I know of is the one that was used in the 1940s by Laxmanshastri Joshi while compiling the Dharmakośa, which he says he obtained from his teacher, the famous Mīmāṃsaka Kevalānanda Sarasvatī (vol. 2.2 p. 525). For a more precise description, see below, Section 2. 
This is surprising indeed, as this commentary is not only a presumably major work by one of the most famous ancient Indian writers, but it also raises interesting questions as to the nature of the AiU itself. Already F. Max Müller, in the introduction to his English translation of the Âranyaka, felt the necessity to distinguish the AiU from what he named the 'Mahaitareya-upanishad, also called by a more general name Bahvrika-upanishad, which comprises the whole of the second and third Âranyakas' (1879, xcvii). ${ }^{8}$ And in fact, some authors in the Śankaran tradition seem to consider that the Upanișad consists of the whole of äranyakas 2 and 3, not only the small portion usually found in printed editions (especially when they include Sankkara's commentary). ${ }^{9}$ It should also be noted that Madhva $\left(12^{\text {th }} \mathrm{c}\right.$.), the founder of the dualist Vedāntic tradition bearing his name, commented on the 'longer' version of the Upanișad, ${ }^{10}$ and that the $17^{\text {th }}$-century Persian translation of the same included most of the second a ranyaka. ${ }^{11}$ It is therefore unclear whether there existed one AiU (then again, in three or nine adhyāyas?), two (the 'larger' encompassing the 'shorter', or the Bahvrca and Saṃhitopanișad?), three (as F. Max Müller seems to suggest), or if asking such a question is even legitimate without further specification (for whom, for what tradition, in what period, etc.?); yet it is easy to see that answering this question has considerable bearing on the comprehension of the Upanișad, as well as on the chronology of the older, 'Vedic' Upanișads. ${ }^{12}$

8 In his earlier History of Ancient Sanskrit Literature (1859), Müller already distinguished be-

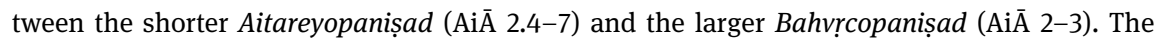
name Bahvṛca-[brāhmaṇa-]upanișad, 'the Upanișad of the Brāhmaṇa belonging to the Bahvrrca (= the Veda 'of many hymns,' a common designation of the Rgveda),' is found in Śankara's commentary on AiĀ 2.1 (see below, Section 1), to which Müller may have had access through manuscripts. The title Mahaitareyopanișad, 'The Greater Aitareyopanișad,' taken up by Keith (1909, 11), is found in the colophon of some manuscripts, though this is by no means the rule and may be limited to works in the Mādhva tradition (as suggested by K.S. Narayanacharya [1997, iii]). See for instance Keith \& Winternitz, Bodleian No. 1011 (p. 77), a Mādhva sub-commentary on the 'longer' AiU by Viśveśvaratīrtha (see also below, n. 56). Earlier in his introduction (p. xciii), Müller spoke of three Upanișads, the 'first Upanișad' corresponding to AiĀ 2.1-3, the second to what is generally known as the AiU ( $\mathrm{Ai} \bar{A}$ 2.4-6/7), and the third being the Saṃhitopanișad ( $\mathrm{Ai} \overline{\mathrm{A}}$ 3). In fact, the colophons of some manuscripts differentiate between the Bahvrcabrāhmaṇopanișad (corresponding to the whole of $\mathrm{Ai} \bar{A}$ 2) and the Samphitopanișad, a distinction which finds some support in Śankara's commentary (see below, Section 1). On this problem, see also the discussion by Keith $(1909,39)$, who rightly concludes that 'the nomenclature was not definitely fixed' even in the late medieval period. Max Müller's divisions of the Aitareya-corpus are taken up in the classical monograph by Renou $(1947,45)$, as well as in the recent study of older Upanișads by S. Cohen (2008, see especially p. 133).

9 Consider for instance the following statement by Sāyana, the famous $14^{\text {th }}$-century commentator on the Veda, in the introductory verses to his commentary on AiĀ 2 (verse 4): äranyakam 
My interest in Sankara's text was awakened by the identification, in 2013, of a complete manuscript of Śankkara's 'longer' commentary unknown to Keith and Belvalkar in the Cambridge University Library (UL Add.2092). ${ }^{13}$ This was immediately followed by the discovery, in 2014, of a second complete manuscript of the text (UL

dvitīyam ca tṛtīyam ca tadātmakam | jñānakāndạn tatah sopaniṣad ity abhidhīyate ||; 'The second and third āranyakas [of the AiĀ], since they consist in [knowledge], are the 'section on knowledge' (jñannakāṇa); this is why they are called an 'Upanișad' (p. 81 - quoted by Belvalkar [1930, 243-244] and Laxmanshastri Joshi [Dharmakośa - Upanișatkāṇda vol. 2.2, p. 525]). The 'etymological' link between jñāna and upanișad is directly inspired from Śankara's commentary (see below, Section 1). The $18^{\text {th }}$-century commentary on AiU by the Advaitin Upanișadbrahmayogin, first published in 1935 in Madras (Adyar Library and Research Centre; second edition Madras, 1984), also deals with the whole of ãranyaka 2. The editor of the text, C. Kunhan Raja, remarks that '[it] follows more or less the Bhāṣya of Śaṃkarācārya' (preface p. vii).

10 See the short notice by B.N.K. Sharma (2000, 168-170); remarkably, the great historian of the Dvaita school acknowledges the existence of Śankkara's 'longer' commentary, which he still considers unpublished, and takes it as an argument against the common view that Madhva, by commenting on the whole AiA $2-3$, would have departed from earlier commentarial tradition. The Viśiștādvaita tradition of Upaniṣadic commentary is relatively late as far as the AiU is concerned. The oldest commentary available in print, by Raṅgarāmānuja (around 1630 according to Potter, see https://faculty.washington.edu/kpotter/ckeyt/txt4.htm), was published in 1951 in Tirupati (reprint: Madras, 1973) and deals with the 'shorter' version of the Upanișad. The same holds for all four commentaries in that tradition (including that by Ranggarāmānuja) published in 1997 by the Academy of Sanskrit Research in Melkote.

11 According to F. Max Müller (1879, xcvii), the translation made in the mid-1 $7^{\text {th }}$ century for Dārā Shikoh, that would be the basis for Anquetil Duperron's translation into Latin in the early $19^{\text {th }}$ century, covers $\mathrm{Ai} \bar{A}$ 2.1.1-2.3.4 and 2.4-2.7, equivalent to the whole second arranyaka with the exception of AiĀ 2.3.5-8. On this translation, see also Keith 1909, 14.

12 The question whether or not to include the beginning of $\mathrm{Ai} \overline{\mathrm{A}} 2$ into the text of the Upanișad is considered in detail by A.B. Keith (1909), who concludes after a lengthy discussion (pp. 4043) that AiĀ 2.1-3 may well be 'the oldest longer Upanișad,' while AiĀ 2.4-6/7 would represent a further development. On this point, see also the critical remarks by E.J. Rapson (1910, 894895), who mentions the opposite views of Deussen. It is not my purpose to engage here in a full discussion of Keith's arguments, mainly based on the evolution of doctrine. I find it surprising, though, that recent studies of Upanișadic literature, like that by S. Cohen (2008), do not even take this possibility into account. While Cohen rightly claims that 'chronological considerations are necessary in order to analyse the text of the Upanișads' (p. 1) and that 'the philosophical discussions in the Upanișads can[not] be fully understood without a chronological perspective,' Chapter 5 of the book, devoted to the AiU, still takes as a matter of fact that 'the Aitareya Upanișad is a short prose text in three chapters (...) commonly regarded as one of the oldest Upanișads, though younger than the Bṛhadāranyaka or the Chāndogya Upanișads' (p. 133). Unsurprisingly, Cohen's linguistic and doctrinal analysis of the 'short' Upanișad (pp. 133-137) confirms this common view, without however raising at any moment the issue of its inscription into the $\mathrm{Ai} \bar{A}-$ corpus, or even mentioning Keith's views on the subject.

13 Online description (with images): https://cudl.lib.cam.ac.uk/view/MS-ADD-02092/1. 
Or.2400) by Elisa Ganser, who was then cataloguing a group of palm-leaf manuscripts from Kerala acquired in the 1990 s by the UL. ${ }^{14}$ The fact that the Cambridge University Library alone possessed two hitherto unknown manuscripts of the work, bought in very different circumstances and clearly unrelated (one a late $16^{\text {th }}$-century copy from Benares, the other a modern South Indian manuscript), made me think that it may be more diffused than originally thought by Belvalkar, and that the latter's claim that 'there does not exist [...] even a single manuscript of the work in India' ${ }^{15}$ might not be entirely true. Regular visits to South Indian libraries following my affiliation to the Pondicherry Centre of the École française d'Extrême-Orient (EFEO) in 2016 confirmed this intuition, leading to the identification of three more manuscripts, one incomplete (Madras, GOML D-331 / SD 183), the other two complete, kept in the Vadakke Madham in Thrissur and in the ORIML in Trivandrum (No. 6312), the last two either uncatalogued or wrongly catalogued (see below, Section 2). The material collected so far, for the most part in the form of digital images, includes eight manuscripts in four different scripts (Devanāgarī, Telugu, Grantha and Malayalam), ${ }^{16}$ and points to a fairly large diffusion (though without comparison with that of the 'shorter' version ${ }^{17}$ ) in a wide geographical area, predominantly Benares and the far South (including the Andhra region); I have no doubt that more research in Indian collections will lead to the discovery of further copies of the text.

The purpose of this essay is to present a temporary state of the art on Śankara's 'longer' Aitareyopanișadbhāṣya, based on past scholarship as well as on my own cursory inspection of the two Cambridge manuscripts and the two editions of the text. This is meant as a preliminary to its complete critical edition, which I plan to achieve in the next few years in collaboration with other researchers of the Pondicherry EFEO Centre. The article is divided in two parts: first of all, I will address the issue of the 'authenticity' of the 'longer' Bhāṣya, and the (very limited) debate to which it gave rise among Indian scholars. Having concluded that the ascription of the text to Sankara is likely to be justified, I will then survey the material so far available for the study of this important, though badly neglected piece of Indian traditional scholarship.

14 Online description: https://cudl.lib.cam.ac.uk/view/MS-OR-02400/1.

15 Belvalkar 1930, 242.

16 Unless the Benares lithograph was based on the Cambridge manuscript, and was realised before its acquisition by the UL - which remains possible - it is unlikely that any of these manuscripts has been used to establish the text of Śankara's Bhāṣya.

17 The NCC 3 (p. 88) lists about a hundred manuscripts of Śankara's 'shorter' Bhāșya. It is, of course, by no means excluded that some of the records actually 'hide' the long version of his commentary, as was the case with the Trivandrum manuscript of AiUBh-L (see below, Section 2). 


\section{On the authenticity of Śańkara's 'longer’ Aitareyopanișadbhāșya}

The question of authenticity is almost inevitably raised while speaking of a work attributed to Śankkara, to whom hundreds of Sanskrit texts (philosophical treatises, stotras, etc.) have been ascribed over the centuries. This is even more the case for a text like the 'longer' AiUBh, which goes against a long, well-established tradition. In this first section, I will summarize the debate as it now stands, and argue that, until otherwise proved, the text under consideration should be regarded as a work by the great Advaitin, indeed as a more complete version of his commentary on the $\mathrm{AiU}$, of which AiUBh-S is just a fragment, or, possibly, as the conflation of two separate commentaries on $\mathrm{Ai} \overline{\mathrm{A}} 2$ and $3 .^{18}$

The authenticity of AiUBh-L has rarely been put into question, mostly because so few scholars seem to have been aware of its existence. In a Sanskrit note to his recent edition of Śañkara's Bhāṣyas (Upaniṣadbhāṣyam vol. 1, p. 630, n. 1), S. Subrahmanya Shastri nevertheless challenges the attribution to Sankara of AiUBh-L, which he knows only from its reprint in the Dharmakośa. As he rightly observes, the prose introduction of the text contains an extensive discussion on the relation (sambandha) of the Upaniṣad - the 'section on knowledge' (jñānakānḍa) - with the 'section on rites' (karmakāṇda) of the Veda, which exactly matches that

18 The question of the 'authenticity' of works ascribed to Śankara is complex, and has been the subject of a number of studies in the past. An argument generally considered decisive in favour of the authenticity of Upanișadic commentaries ascribed to Sankara is the existence of an old subcommentary, like the Vārttikas by Sureśvara, which is missing in the present case. Most discussions of disputed works are otherwise based on their comparison with Śankara's Brahmasūtrabhāșya, considered the cornerstone of any further attribution, especially on the use of certain concepts like $m \bar{a} y \bar{a}$, avidya and the like. See for instance the discussion of the two versions of the Kenopanișadbhāssya by S. Mayeda (1968), who concludes on this basis that both commentaries should rightly be ascribed to the great Advaitin. My purpose here will be more limited, as I temporarily take the authenticity of the commentary on AiU for granted. Given that this text has been transmitted in two versions (the 'longer' and the 'shorter'), the only purpose of the present enquiry is to decide whether the 'longer' version, relatively marginal in the transmission, is the result of later accretions, or whether it is rather the 'shorter' version, normally found in printed editions, which is incomplete. This, of course, does not exclude further investigations on the concepts used by the author of this commentary while dealing with the Aitareya-corpus. It is my hope, however, that these preliminary remarks will help us doing so on a more solid textual basis. 
found at the beginning of Saṅkara's Bṛhadāranakopanișadbhāṣya. ${ }^{19}$ This redundancy leads him to doubt the attribution of the text to Śankara: 'of course', he says, 'it is not proper [for Śankara] to say the same thing here as well, for we see that [he] writes different introductions for different Upanișads.' Such a weak argument, especially when coming from a renowned Indian pandit, mainly proves, in my opinion, the tenacity of reading habits when a text has become 'well-known everywhere in India' (sarvatra bhāratadeśe prasiddhah), that is, after one has become accustomed to seeing it printed in books. Repetition of the same passage in various works of the same author is a daily observation in Sanskrit scholastic literature, and Sankara's writings are no exception to that rule, as can easily be seen from his other Upanișadic Bhāşyas. The parallel pointed out by Subrahmaṇya Shastri could therefore be used to prove exactly the contrary, namely that both introductions were written by one and the same person.

In fact, the proximity between the introduction to AiUBh-L and other reputedly authentic Upanișadic commentaries by Sañkara is striking. As Belvalkar already noted, the 'vulgate' version of AiUBh starts 'abruptly' with the statement parisamāptam karma sahāparabrahmavișayavijñānena; 'The [discussion of the] rite (karman) is [now] over, as well as the [discussion of] the knowledge of the inferior Brahman.' Other Upanișadic commentaries ascribed to Śankara, on the other hand, usually start with a rather stereotyped introduction including typical elements such as the first words of the Upanișad, ${ }^{20}$ the title of the work commented (or an indication of the corpus to which it belongs), ${ }^{21}$ a statement of the author's intention to write something 'brief' (sampksepatah, alpagrantha, etc.), ${ }^{22}$ a semantic analysis (nirvacana) of the word upanișad, ${ }^{23}$ and a general discussion of the relation

19 See Bṛadāranyakopanișadbhāșya p. 2sq. I refer, throughout this article, to the text of Śaṅkara's Upaniṣadic Bhāṣyas as it is printed in the three volumes entitled Upanișadbhāşyam, edited by S. Subrahmanya Shastri and published together with Ānandagiri's sub-commentaries by the Mahesh Research Institute in Benares.

20 Together with the discussion of sambandha, this is perhaps the most stable feature of the introductions to Śankkara's Upanișadic commentaries; it is found at the beginning of his Bhāṣyas on BĀU, ChU, İsāu, KeU, MuU and MāU. The only exceptions to this rule are the Bhāṣyas on KāU and PraU, as well as that on TaiU, which starts in a very unusual way with a mangala, followed by the discussion of sambandha.

21 Bhāṣyas on BĀU (vājasaneyibrāhmaṇopanișad), ChU (așțādhyāyī chāndogyopanișad), TaiU (taittirīyakasāra), KāU (kāțhakopanișadvallī) and MāU (ātharvaṇopanișad).

22 Bhāṣyas on BĀU (alpagranthā vṛttir ārabhyate), ChU (saṃkṣepato 'rthaijijñāsubhyo vivaraṇam alpagrantham ārabhyate), KāU (sukhārthaprabodhanārtham alpagranthā vṛttir ārabhyate).

23 Bhāsyas on BĀU, TaiU and KāU (where this nirvacana is dealt with in great detail; see below); the absence of this element in ChUBh is indeed remarkable. 
(sambandha) of the Upanișad with the 'section on rites' (karmakāṇa). ${ }^{24}$ This is exactly what we find at the beginning of the introduction of AiUBh-L. ${ }^{25}$ Let us quote only its initial part, which precedes the long discussion of sambandha ${ }^{26}$ :

eșa panthā ityādyā bahvrcabrāhmaṇopanișat | tasyā idaṃ vivaraṇam alpagranthaṃ sukhāvabodhārtham ${ }^{\mathrm{a}}$ ārabhyate ${ }^{\mathrm{b}}$ | upanișad ity upanipūrvasya sadeh kvibantasya viśaraṇagatyavasādanārthasya rūpam ācakșate | viśeșeṇa copanișacchabdavācyātmavidyāa $\mid$ tādarthyād grantho 'py upanișat | ye hy asyām ātmavidyāyām tātparyenopātmatayā vartante ātmavidyānișthās teșām avidyādisaṃsārabijadoșam ${ }^{\mathrm{d}}$ avasādayati vināśayati | paraṃ cātmānaṃ nigamayaty avabodhayati | garbhajanmajarārogādīmśs ca niśātayati ${ }^{\mathrm{e}}$ | ata iyam ${ }^{\mathrm{f}}$ àtmavidyopanișat | tadupakārakatvāt prāṇādividyānām apy upanișattvam | so 'yam ātmavidyāvișkaraṇāyaișa panthā ityādigrantho vyācikhyāsitah|

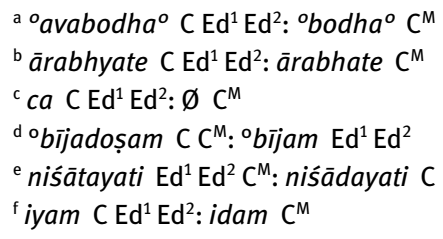

With the words eșa panthāḥ ('This is the path') begins the Bahvrcabrāhmaṇopanișad. We [now] undertake [to compose] a gloss (vivarana) of it, in few words (alpagrantham), for an easy understanding. They say that upanișad is a form of the root $\mathrm{vsad}$, which has the sense of either dissolution (viśarana), motion/intellection (gati) or perishing (avasādana), ${ }^{27}$ preceded by [the preverbs] upa and $n i$ and followed by [the zero krt-affix] kvip (A 3.2.61). Specifically, what is referred to by the word upanișad is the knowledge of the Self ( $\bar{a}$ tmavidy $\bar{a})$. A text that has [such a knowledge] as its [main] topic is therefore also called [an Upanișad]. To explain: for those who only aim at this knowledge of the Self, for whom it has become a second nature (upātmatā), who are abiding in the knowledge of the Self, it [i.e., the upanișad] annihilates ( $\left.a v a-\sqrt{ } s a d^{\text {caus }}\right)$, [which means that it] destroys $\left(=v i-\sqrt{ } n a \hat{s}^{\text {caus }}\right)$ the defect that is the seed of samsāra, [namely] nescience and the like. Moreover, such a [text] transmits scripturally (ni-

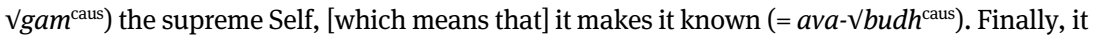
lays to rest (niśătay-) the birth into a womb, old age, illness, and the like. Therefore, this knowledge of the Self is [literally] upanișad. Since they assist it, knowledge (vidyā) about the breath (prāna), etc. are also upanișad..$^{28}$ It is to reveal this knowledge of the Self that [we] intend to comment on the text beginning with [the words] eșa panthāh.

24 Bhāṣyas on BĀU, ChU, TaiU, ĪsāU and KeU.

25 The beginning of the text could not be examined by Belvalkar, as it was missing in the only manuscript to which he had access. Our observations, however, essentially confirm his conclusions.

26 For a precise correspondence of sigla, see the table at the end of the article.

27 Cf. Dhātupāțha 1.907 / 6.133: șad(lṛ) viśaraṇagatyavasādaneșu (see Böhtlingk 1998).

28 This may be a reference to the AiĀ 2.2, which extensively deals with the doctrine of prāna, or to the whole of $\mathrm{AiA} \overline{\mathrm{A}} 2.1-3$, where prāna plays a prominent role. 
A strikingly close parallel to this introduction is found in Śankkara's commentary on $\mathrm{BA} U$, which contains essentially the same items ${ }^{29}$ :

uṣā vā aśvasya ityevamādyā vājasaneyibrāhmanopaniṣat | tasyā iyam alpagranthā vrttir ārabhyate samsāarravyāvivṛtsubhyaḥ saṃsārahetuniṿ̛ttisādhanabrahmātmaikatvavidyāpratipattaye | seyam brahmavidyopaniṣacchabdavācyā, tatparāṇām sahetọ̣ saṃsārasyātyantāvasādanāt, upanipūrvasya sadeh tadarthatvāt | tādarthyād grantho 'py upanișad ucyate |

With the words ușā vā aśvasya ('Dawn, to speak the truth, is [the head] of the horse [of the sacrifice]') begins the Vājasaneyibrāhmaṇopanișad. We [now] undertake [to compose] a gloss (vrtti) of it, in few words, in order to convey the unity of the Self with Brahman, which leads to the cessation of samsāra and its cause, for the sake of those who wish samsāra to come to an end. This knowledge of the Brahman is what is referred to by the word upanișad, for samsāra together with its causes is annihilated (ava-Vsad/caus.) for those who only aim at this [knowledge of the Self], and such is the meaning of the root $\mathrm{V} s a d$, which [in that case] is preceded by [the preverbs] upa and ni. A text that has [such a knowledge] as its [main] topic is therefore also called an Upaniṣad.

Impressive similarities with the introduction to Sankara's other Upanișadic Bhāssyas could be shown for any of the typical elements enumerated above. Consider, for instance, the analysis of the term upanișad found in his commentaries on KāU and TaiU:

\begin{abstract}
Bhāṣya on $\mathrm{Ka}^{30}$
sader dhātor viśaraṇagatyavasādanārthasyopanipūrvasya kvippratyayāntasya rūpam upanișad iti | upanișacchabdena ca vyācikhyāsitagranthapratipādyavedyavastuvișayā vidyocyate | kena punar arthayogenopanișacchabdena vidyocyata iti | ucyate | ye mumukșavo dṛ̦țānuśravikavișayavitṛ̦ṇāḥ santa upanișacchabdavācyāṃ vakșyamāṇalakșaṇāṃ vidyām upasadyopagamya tannișthatayā niścayena śillayanti, teșām avidyādeh saṃsārabījasya viśaraṇād dhimsanād vināsanād ity anenārthayogena vidyopanișad ity ucyate |

[The word] upanișad is a form of the root $\mathrm{V} s a d$, which has the sense of either dissolution (viśarana), motion/intellection (gati) or perishing (avasādana), preceded by [the preverbs] upa and $n i$ and followed by [the zero krt-]affix kvip. What is referred to by the word upanișad is the knowledge of that object [= the Self], worthy to be known, which is conveyed by the text that [we] are about to explain. [One may ask:] by which semantic connection (arthayoga) does the word upanișad refer to 'knowledge' (vidyā)? The answer is [as follows: this is because,] considering those [people] who, desirous of liberation, do not crave for objects which are either seen or heard of [in Scriptures], come near (upa-Vsad), i.e. approach (upa-Vgam) that knowledge which is referred to by [the word] upanișad, the characters of which we are about to explain, [and having done that] cultivate it decidedly (niścayena śillayanti) by abiding in it
\end{abstract}

29 Brhadāranyakopanișadbhāṣya pp. 1-2.

30 Kāṭhakopanișadbhāṣ̂ya pp. 55-57. 
(tannișthatayā), for them the seed of samsāra, [namely] nescience and the like, gets dissolved, [in other words it] gets killed (himsana), destroyed (vināśana); such is the semantic connection by which 'knowledge' is called upanișad.

\begin{abstract}
Bhāṣya on TaiU ${ }^{31}$
upanișad iti vidyocyate, tacchīlinām garbhajanmajarādiniśātanāt, tadavasādanād vā, brahmaṇo vopanigamayitṛtvāt, upanișaṇnạ̣ vāsyāṃ param śreya iti | tadarthatvād grantho 'py upanișat |
\end{abstract}

The word upanișad means knowledge (vidyā), for those who cultivate it lay to rest (niśātay-) the birth into a womb, old age, etc., or because it annihilates [these ills] (ava-vsad/caus.), because it leads to the knowledge (upani-Vgam) of Brahman, or because the Supreme Good is residing (upanișaṇna) in it. A text that has [such a knowledge] as its [main] topic is therefore also called an Upanișad.

External evidence also points in the direction of Śankara's authorship of AiUBh-L. Two sources need to be taken into account here: the testimony of Sāyana $\left(14^{\text {th }} \mathrm{c}\right.$.), and the paratextual elements found in editions and manuscripts of AiUBh-L.

In the opening verses of his commentary on $\mathrm{AiA}$ 2, Sāyana states that he composed his work 'following the path [laid down by] Śañkarācārya' (śañkarācāryavartmanā.$^{32}$ And in fact, his Bhāssya on $\mathrm{Ai} \bar{A}$ 2.1-3, at least, shows evident debt to the commentary attributed to the great Vedāntin. This is not only true of the long 'philosophical' introduction on sambandha, where Sāyaṇa follows Śankkara at every step (beginning with the gloss of the word upanișad found at the very start of his commentary $\left.{ }^{33}\right)^{34}$. He is also indebted to the $8^{\text {th }}$-century Advaitin in the detail of

31 Taittirīyopanișadbhāṣya p. 371, 1. 3-4.

32 Sāyaṇa’s Bhāṣya on AiĀ 2 (introductory verse 5ab): karomy upanișadvyākhyām șánkarācāryavartmana |; 'I compose this commentary on the Upanișad, following the path of Śankkarācārya' (p. 81). This fact was already noted by Belvalkar $(1930,244)$. Recall that by 'the Upaniṣad' Sāyaṇa means the whole of āranyakas 2 and 3, not only the 'shorter' AiU (see above, n. 9).

33 See Sāyaṇa’s Bhāṣya on AiĀ 2.1.1: upanișacchabdo brahmavidyām ācașțe | sā hi vivitsum puruṣam upetya nitarām avidyāṃ sīdati viśīrṇām karoti, yad vā brahmatām gamayati, atha vā rāgadveșā̄v avasādayati śithilikkaroti | tataḥ 'șaḍlḷ viśaraṇagatyavasādaneșu' iti proktaṃ dhātor arthatrayam tasminn upanișacchabde <em: ${ }^{\circ}$ chabdo ed.> vidyate. tathāvidhāya brahmavidyāyā utpādakatvād grantho 'py upanișad ity ucyate |; 'The word upanișad expresses the knowledge of Brahman. For [such a knowledge], having approached a person desirous to know, exhausts ( $\vee s a d)$, i.e. dissolves (viśírnām karoti) nescience; or, it leads (gamay-) [that person] to the state of Brahman; or [finally] it causes passion and aversion to perish ( $\left.a v a-v s a d^{\text {caus }}\right)$, i.e. it loosens their ties. Therefore, the three meanings spoken of [in the Dhātupātha when it says] 'the root vsad [is used in the sense of] dissolution, motion and perishing' are present in the word upanișad. Since it generates such a knowledge of Brahman, the [corresponding] text is also called an 'Upanișad' (p. 81, 1. 11-15). 
his explanation of the Āranyaka. Consider, for instance, the two commentators' explanation of the beginning $\operatorname{Ai} \bar{A}$ 2.1.1:

\author{
$\mathrm{Ai} \overline{\mathrm{A}} 2 \cdot 1 \cdot 1^{35}$ \\ eșa panthā etat karmaitad brahmaitat satyam | tasmān na pramādyet tan nātīyāt | na hy \\ atyāyan pūrve, ye 'tyāyaṃs te parābabhūvuh |
}

This is the path, this is the sacrifice, this is Brahman, this is truth. Let no man diverge from it; let no man transgress it; of old, they did not transgress it; those that did transgress it were overcome. ${ }^{36}$

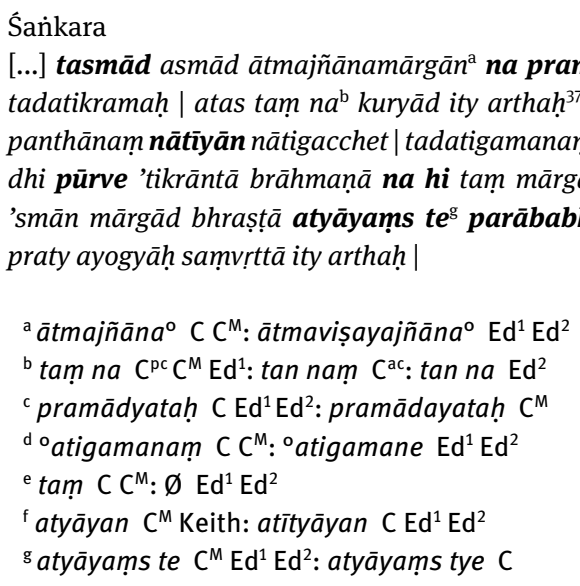

Śaṅkara praty ayogyāh samvrụttā ity arthạ! |

[...] tasmād asmād ātmajñānamārgānn na pramādyet pramādo na kartavyaḥ | pramādas

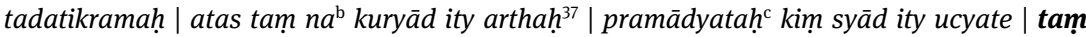
panthānaṃ nātīyān nātigacchet | tadatigamanam ${ }^{\mathrm{d}}$ ca doșaḥ | tasmāt taṃ ${ }^{\mathrm{e}}$ na kuryāt, yasmād dhi pūrve 'tikrāntā brāhmaṇā na hi tam mārgam atyāyan nātigatavanta ity arthah | ye 'smān mārgād bhrașțā atyāyamss te $\boldsymbol{e}^{\mathrm{g}}$ parābabhūvuh parābhūtāh karmajñānānușṭhānam

Let no man diverge; [this means:] one should have $(v k r)$ no divergence from it, i.e. from that path [leading to] the knowledge of the Self. 'Divergence' (pramāda) means stepping beyond (atikrama) the [path]. One should not undertake ( $/ k r$ ) to [step beyond] the [path]; this is the meaning. ${ }^{38}$ [If one asks] what will happen to those who diverge from it, the answer

34 Keith $(1909,199$, n. 1) notes a similar proximity between Sāyaṇa’s introduction and Śańkara's Taittirīyopanișadbhāṣya (ad TaiU 1.12).

35 The text of the Āranyaka is given in accordance with its critical edition by A.B. Keith (1909). 36 I slightly modify the translation by Keith $(1909,199)$, reading pūrve with atyāyan as Śankara and Sāyaṇa recommend; Keith's choice to read it with what follows is, of course, also possible. I also suppress 'therefore' in order to avoid a double use of tasmād.

37 The whole gloss following na pramādyet in C and the editions, namely pramādo na kartavyah | pramädas tadatikramah | atas tam na kuryād ity arthaḥ | is entirely missing in $\mathrm{C}^{\mathrm{M}}$. Instead, after na pramādyet we find the simple addition of the phrase tasmät pathah. This does not seem to be explicable by a simple slip of the pen.

38 Although this might not be entirely clear from my translation, Sańkara's main intention here is to gloss the rather vague term pramāda ('divergence' in Keith's translation, or simply 'erring') 
is that no man should transgress, i.e. go beyond (ati- $/ \mathrm{gam})$ that path, and that going beyond [that path] is a fault. One should not do that, because it is well known that of old, the ancient Brahmins did not transgress it, i.e. they did not go beyond it; this is the meaning. Those that, fallen down (bhrașta) from that path, did transgress it were overcome, they have been overcome, that is, they became unable to perform either the rites or [salvific] knowledge $\mathrm{e}^{39}$; this is the meaning.

\section{Sāyana ${ }^{40}$}

tasmād ubhayavidhād āmnāyamārgāt pramādam na kuryāt | karmānușthānabrahmajñānayor asampādanam pramādah | nātīyāt [...] nātikrāmet | [...] pūrve maharșayo vyāsavasișțhādayas tam uktaṃ panthānam naivātyāyan nātyakrāman | ye tu nāstikā atyakrāmaṃs te parābabhūvuḥ parābhūtāḥ puruṣārthād bhrașțāḥ|

[Let no man diverge] from it; [this means that] one should not diverge from the two-fold path [described] in the Scriptures [i.e. the path of the rites and the path of knowledge]. ${ }^{41}$ 'Divergence' (pramāda) means the fact of not achieving (asampādana) the performance of the rites and the knowledge of Brahman. Let no man transgress [...], [this means:] let no man step beyond (ati-Vkram) [the path]. [...] Of old the great Sages like Vyāsa or Vasiștha did not transgress the mentioned path at all, i.e. they did not step beyond it. But those heretics (nāstika) who went beyond it were overcome, they have been overcome, [that is] they fell down (bhrașta) from the goal of man.

There are no doubt minor differences between the two texts, which might as well be significant from the point of view of the history of ideas. ${ }^{42}$ But the structure of the explanation and the glosses of specific terms are obviously the same, and this remark can be extended to large parts of Sāyaṇa's commentary on $\mathrm{Ai} \overline{\mathrm{A}} 2-3$. Thus it seems certain that Sāyaṇa was drawing his inspiration from a text he, at least, believed to be by Śankara, and that this text corresponds to the one transmitted in our manuscripts of AiUBh-L.

by the more precise term atikrama ('stepping beyond', 'transgression'), and also to link it syntactically with the ablative tasmād, which in principle could also be interpreted as 'therefore', as in Keith's translation of the Āranyaka.

39 As we can see from the passage quoted below, the slight oddity in speaking of karmajñannanușțānam ('The performance of the rites and [salvific] knowledge') is suppressed by Sāyaṇa, who chooses to mention separately karmānușthāna ('the performance of rites') and brahmajñāna ('the knowledge of Brahman').

40 Sāyaṇa's Bhāṣya on AiĀ 2.1.1, p. 86, 1. 26 - p. 87, 1. 4.

41 Interestingly enough, the two-fold path is described in a slightly different way in Śankara's commentary, as consisting of the path of the rites and the path of Yoga.

42 The mention of 'heretics' (nāstika), for instance, seems to be an addition by Sāyaṇa, who also alludes to the typically Buddhist practice of 'revering reliquaries' (caityavandana - p. 86, 1. 29), thus giving to his commentary a more neatly apologetic flavour. 
In addition to Sāyaṇa's testimony, paratextual elements found in editions and manuscripts (title pages, rubrics, etc.) offer another kind of external evidence, if not directly for Sankara's authorship, ${ }^{43}$ at least for the unity of the old Bhāṣya on $\mathrm{Ai} \overline{\mathrm{A}}$ 2-3.

The Benares 1884 lithograph mentions the work under the name Aitareyopanișadbhāṣya, found on the title page (fol. 1v) as well as in rubrics concluding adhyāyas 1-5, which are numbered continuously. ${ }^{44}$ The rubric of the sixth adhyāya mentions it under another title, Bahvrcabrāhmaṇopanișadbhāṣya, and considers the work bearing that name to be 'finished' (samāpta) with that adhyāya (recall that adhyāya 2.6 is the last commented on by Sankara in the second aranyaka)..$^{45}$ The rubric found at the close of the commentary on $\mathrm{Ai} \overline{\mathrm{A}} 3.1 \mathrm{in}$ troduces yet another title, Samphitopanișadbhāșya, thus speaking of 'the first book of the Samhitopanișadbhāṣya, [which is part] of the Bahvrcabrāhmaña ${ }^{46}$ [corresponding to] the third äranyaka' (bahvrcabrāhmaṇe saṃhitopaniṣadbhāṣye tṛtīyāranyake prathamo 'dhyāyah - fol. 64v1). The final rubric of the work wrongly numbers the second adhyāya 'third,' but is otherwise quite similar to the preceding one, except that it calls the brāhmaṇa Aitareya ${ }^{\circ}$, not Bahvrca $^{\circ}$ (the two terms may be synonym in that context). ${ }^{47}$ To summarise, the first 'edition' of the text (which, as we shall see, is little more than the printed copy of a North Indian

43 It is remarkable, still, that all consulted sources agree in attributing the work to 'Śankkara Bhagava(n)t,' the disciple of 'Govinda Pūjyapāda.' This, according to P. Hacker (1995, 41-56), is one of the decisive criteria in favour of the authorship of a given work by Śankara. For a more precise formulation of Hacker's criteria, leading to the same conclusion, see Harimoto (2014, 242-243).

44 The rubric that concludes the commentary on $\mathrm{Ai} \bar{A} 2.1$ reads as follows: iti śrigovimidabhagavatpūjyapādaśișyaparamahaṃsaparivrājakācāryaśrīmacchaṃkarabhagavatạ̣ kṛtāv aitareyopanișadbhāṣye prathamo 'dhyāyaḥ (fol. 10v12-13). Similar rubrics are found with minor variations on fol. 14r7-11 (no mention of Govinda) and fol. 22v12 (abbreviated, no title given). The rubric closing the fourth adhyāya gives a different title, Aitareyabhāssya (without ${ }^{\circ}$ upanișad $^{\circ}$ ), but does not break the continuity in the count of adhyāyas: ity aitareyabhāssye dvitīyāranyake caturtho 'dhyāyah (fol. 42v8-10). The rubric following the fifth adhyāya (fol. 52v11-12) is identical in structure, but has the 'full' title Aitareyopanișadbhāṣya (instead of Aitareyabhāṣya).

45 The full rubric reads as follows: iti śrīmatparamahaṃsaparivrājakācāryaśrīgoviṃdabhagavatpādapūjya[sic]śișyaśrīmacchaṃkarācāryabhagavatạ̣ kṛtau bavṛcabrāhmaṇopanișadbhāṣyam samāptam (fol. 57v7-10).

46 It is not impossible that the expressions Aitareyabrāhmaṇa and Bahvrcabrāhmaṇa should be understood as abbreviations of Aitareya /Bahvrcabrāhmaṇa-upanișad. The Saṃhitopanișad would then be the last part of that Upanișad in the mind of the editor.

47 AiUBh-L $\left(\mathrm{Ed}^{1}\right)$ fol. 70v14-15, iti śrīgoviṃdabhagavatpūjyapādaśișyaparamahaṃsaparivrājakācāryasya śrīmacchaṃkarabhagavatạ̣ kṛtāv aitareyabrāhmaṇe saṃhitopanișadbhāṣye tṛtīyo'dhyāyaḥ. samāptā ceyaṃ bahvṛcabrāhmaṇopaniṣat. 
manuscript) provides us with three titles - Aitareya[-upanișad]-bhāṣya, Bahvrcopanișadbhāṣya and Saṃhitopanișadbhāșya - applied without consistency to parts of the work and (with the exception of the last) also to the whole. Given this confusing situation, it is quite understandable that Laxmanshastri Joshi, in the 1949 reprint of the editio princeps, felt the need to 'normalise' the rubrics by uniformly speaking of 'the Bhāsya on the second / third äranyaka of the Aitareya[āranyaka]' (aitareya-dvitīya $\%$ trtīyāranyakabhāṣya), still numbering the adhy āyas continuously from 1 to 6 (for $\mathrm{Ai} \overline{\mathrm{A}} 2$ ), then from 1 to 2 (for $\mathrm{Ai} \overline{\mathrm{A}} 3$ ). What is clear, in any case, is that the first editor of the work, no doubt relying on manuscript evidence, did not consider $\mathrm{Ai} \overline{\mathrm{A}} 2.4-6$ to be a separate work, distinct from $\mathrm{Ai} \overline{\mathrm{A}}$ 2.1-3. His main hesitation is whether the title Bahvrcabrāhmanopanișadbhāṣya, taken up from Sankkara's introduction (see above), applies to the whole work or only to the second aranyaka.

This globally corresponds to the information provided in manuscripts. The older of the two Cambridge manuscripts, Add.2092, also numbers adhyāyas continuously from 1 to 6, without break with adhyāya 4, and marks the end of the first five with the brief mention aitareyopanișadi prathamo [, dvitīyo..., pañcamo] 'dhyāyah (fol. 16v5; fol. 21v5; fol. 34v6; fol. 43v8; fol. 48v5). AiĀ 2.6 has a more elaborate rubric, which closely corresponds to that found in the Benares lithograph, especially because it also mentions the text under the title Bahvrcabrāhmaṇopaniṣadbhāṣya. ${ }^{48}$ Leaving aside the brief Sāntipātha, on which Śañkara did not comment, the following adhyāyas clearly mark a rupture; the indication at the end of the commentary on $\mathrm{Ai} \overline{\mathrm{A}} 3.1$ looks corrupt (aimtasyopanișadi [?] prathamo 'dhyāyah), but the commentary on $\mathrm{Ai} \overline{\mathrm{A}} 3.2$ ends with a rubric very similar to that on $\mathrm{Ai} \bar{A}$ 2.6, where the work is named, however, Samhitopanișadvivarana. ${ }^{49}$ Thus it seems that the author of the Cambridge manuscript, unlike that of the Benares lithograph, considered that the text consisted of two partly independent works called Bahvrcopaniṣadbhāṣya (ad AiĀ 2.1-6) and Saṃhitopanișadvivaraṇa (ad $\mathrm{Ai} \overline{\mathrm{A}}$ 3.1-2), nevertheless integrated enough to form a single,

48 AiUBh-L (C) fol. 50v10 - fol. 51r1: śrīmadgoviṃdabhagavatpūjyapādaśișyaparamahamsaparivrājakācāryasya śaṃkarabhagavatah kṛtau bahvṛcabrāhmaṇopanișadbhāṣya[ṃ] samāpta $[\mathrm{m}]$. I emend the aberrant reading ${ }^{\circ}$ bhāșyatah samāptā of the manuscript.

49 See AiUBh-L (C) fol. 70r5-6: śrīgoviṃdabhagavatpūjyapādaśișyaparamahaṃsaparivrājakācāryasya śrīmacchaṃkarabhagavataḥ kṛtau saṃhitopaniṣadvivaraṇaṃ samāptaṃ| 
continuous gloss on $\mathrm{Ai} \overline{\mathrm{A}} 2-3 .^{50}$ If some manuscripts confirm this view, ${ }^{51}$ others lead us to think that the title Bahvrca[-brāhmana-]upanișadbhāṣya/ ${ }^{\circ}$ vivarana rather applies to the whole work, not a part of it, and come closer to the Benares print. ${ }^{52}$

It seems to me that the main reason for such hesitations lies nowhere but in Sankara's text itself. We have already seen that the title Bahvrcabrāhmanopanișadvivarana is given, following Sankara's well-established habit, in the introduction to his 'longer' Bhāssya. What is more surprising is to find the same kind of typically Śankaran introduction, including the mention of a different title and the familiar etymological digression on the word upanișad, at the beginning of his commentary on $\mathrm{Ai} \overline{\mathrm{A}} 3.1^{53}$ :

athātah saṃhitāyā upaniṣad ityādyā saṃhitopanișad |asyā $h^{\mathrm{a}}{ }^{\mathrm{a}}$ saṃkṣepato vivaraṇaṃ karișyāmo mandamadhyamabuddhīnām api tadarthābhivyaktị̣ syā $d^{\mathrm{b}}$ iti | [...] upanipūrvasya sader viśaraṇagatyavasādanārthasya kvibantasya rūpam upaniṣad iti | upaniṣadvijñānam cedaṃ tātparyeṇa | upanișannā ye, teșām vākkāyamanobhir buddher ${ }^{\mathrm{c}}$ anarthapratipattihetubhūtāyā viśaraṇād upanișat | vakșyamāṇaphalaprāpayitṛtvāc copaniṣat saṃsārabījāvidyāvasādanāc copaniṣat |

a asyāh $\mathrm{C} \mathrm{C}^{\mathrm{M}} \mathrm{Ed}^{1}$ : tasyāḥ $\mathrm{Ed}^{2}$

b o abhivyaktih syād $\mathrm{Ed}^{1} \mathrm{Ed}^{2}$ : o abhivyakti syād (!) C C $\mathrm{C}^{\mathrm{M}}$

${ }^{\circ}{ }^{\circ}$ manobhir buddher $\mathrm{C} \mathrm{Ed}^{1} \mathrm{Ed}^{2}$ : ${ }^{\circ}$ manobuddher $\mathrm{C}^{\mathrm{M}}$

With the words athātah samphitāyā upanișad ('Now begins the Upaniṣad of the samphitā') begins the Samhitopanișad. We [now undertake] to compose a gloss (vivarana) of it, in a

50 Since all these titles are likely to be directly extracted from the text of Sankara itself (see below), I do not think much weight should be given to the variations between the titles bhāșya, vivarana (the word used in both cases by Śankara), and țika

51 The colophons of the London manuscript described by Winternitz (Asiatic Society No. 158 [p. 216-217]) also distinguish between a Bahvṛcabrāhmaṇopanișaț̣īka ( $\operatorname{ad} \mathrm{AiA} \overline{\mathrm{A}}$ 2.1-6) and a Saṃhitopanișadvivaraṇa ( $\operatorname{ad} \mathrm{AiĀ} 3)$.

52 This is what we find, for instance in the GOML manuscript described in MD 1.3 under No. 331 (pp. 315-317). From its description in the catalogue, it appears that the manuscript numbers adhyāyas continuously and names the work Aitareyopanișadvivarana in the rubrics (examples are given for adhyāyas 3 and 4), except for the final rubric of adhyāya 6, where it is named Bahvrcabrāhmanopanișadbhāṣya; this last rubric is almost identical to that of the Cambridge manuscript (see above, n. 48), with mention of Govinda and 'Śamkarabhagava(n)t', but a slightly different conclusive formula (bahṿ̣cabrāhmaṇopanișadbhāṣye dvitīyāraṇyakaṃ samāptam - p. 317), which leaves the possibility that arranyaka 2 could be a part of the Bahvrcabrāhmanopanișadbhāșya, not the whole of it.

53 The passage is found on fol. 59r1-7 in $\mathrm{Ed}^{1}$, on p. $597 \mathrm{in} \mathrm{Ed}^{2}$, on fol. 51v9 - 52r6 in C and on fol. 111v8 $-112 \mathrm{v} 5$ in $\mathrm{C}^{\mathrm{M}}$. 
concise way (samkșepatah), so that its meaning becomes fully manifest even to people with a weak or average understanding. [...] [The word] upanișad is a form of the root vsad, which has the sense of either dissolution (viśaraṇa), motion/intellection (gati) or perishing (avasādana), preceded by [the preverbs] upa and ni and followed by [the zero krt-affix] kvip. But essentially (tätparyena), it is the knowledge [consisting in] upanișad. Considering those who have come near (upanișanna) [that knowledge], their soul (buddhi), which is the cause for apprehending what is unwished, together with their speech, body and mind, is subject to dissolution (viśaraṇa), so [for them there is] upanișad. [That knowledge] is also upanișad because it leads (prāpay-) to the [expected] result we are about to explain. Finally, it is upanișad because nescience, which is the seed of samsāra, is annihilated (avasādana).

In view of this, there is indeed ground for hesitating whether to regard the Bahvrca[-brāhmaṇa- $]^{\circ}$ and Saṃhitopanișad (and the corresponding vivaranas) as distinct texts, or the latter as just a sub-section of the former. I find it significant, though, that such a problem does not arise for the Bhāssya on AiĀ 2.4-6 (the 'vulgate' Upanișad), which our sources unanimously consider to be part of the larger commentary on $\mathrm{Ai} \bar{A} 2$.

Now, there is no doubt some logic in considering that the 'shorter' version is the only one authentic. Śankara's statement that a given Upanișad begins only after the investigation of rites (karman) and inferior Brahman (aparabrahma) has been completed (parisamāpta), quoted in the beginning of this section, inevitably recalls the opening portion of other Upanișadic commentaries by the great Advaitin, beginning with that on the Chändogy $a^{\circ}$, where we find the same sentence almost word for word. ${ }^{54}$ One could also argue that the portions of AiA $2-3$ which are generally not considered part of the AiU found their way into Śankara's Brahmasūtrabhạsya, but in very limited proportions. ${ }^{55}$ This is surprising if the AiU is to be included in the group of older, major Upanișads, which are otherwise quoted by Śankara at every page. A further argument is that no sub-commentary has so far been discovered on the 'longer' version of the Bhässya, ${ }^{56}$ and that

54 Chāndogyopanișadbhāṣya (introduction): samastam karmādhigataṃ prāṇādidevatāvijñānasahitam; 'The rite (karman) has been entirely dealt with, together with the knowledge of deities such as the breath (prāna ), etc.' (p. 2).

55 The fairly exhaustive index of quotes found at the end of Anantakrishna Shastri and Vasudev Laxman Shastri Pansikar's edition of Śankkara's Brahmasūtrabhāṣya (p. 1035-1061 in the 2000 reprint) records only five quotes of $\mathrm{Ai} \bar{A}$ 2.1-3 and $\mathrm{Ai} \bar{A}$ 3: $\mathrm{Ai} \bar{A}$ 2.1.2 (two quotes), 2.1.3, 2.3.3 and 3.2.3. Adding quotes from the Upanișad 'proper' ( $\mathrm{Ai} \overline{\mathrm{A}} 2.4-6 / 7$ ), we reach a total of about twenty quotations. This is certainly not negligible, but still without any comparison with, for instance, the hundreds of quotes from the ChU and BĀU found in Śankara's opus magnum.

56 In their 1905 catalogue of the Bodleian manuscripts (Bodleian No. 1011.3 - p. 77), Keith \& Winternitz mention a potentially significant manuscript (Wilson collection No. 401.3), which they de- 
Ānandagiri's standard gloss, as we find it in many printed editions (including the Benares 1884 lithograph) only extends to adhyāyas $4-6 .{ }^{57}$ Similarly, one cannot overlook the fact that the manuscript tradition of AiUBh-S is absolutely overwhelming. ${ }^{58}$

Thus, although I remain convinced by the evidence presented above that the 'longer' version is the only one representing the complete work of Śankkara, I also think it would be misleading to interpret the spread of AiUBh-S only in terms of an editorial 'error' or of a mistaken reading habit. It may rather be the case that both versions of the text were transmitted simultaneously, possibly for different purposes and audiences, and not unlikely in a community of readers who were conscious of their coexistence. ${ }^{59}$ The task of a critical edition of the 'longer' Aitareyopanișadbhāssya will of course be, first of all, to recover an almost forgotten

scribe as 'Viśveśvaratīrtha’s commentary on Ānandatīrtha's commentary on Śaṅkara’s commentary on the second and third āranyakas of the Aitareyāranyaka.' Although I have not seen the manuscript, this identification seems clearly erroneous to me, and in any event is directly contradicted by the authors' subsequent affirmation that 'this Ms. contains from the first adhyāya of the second praghatțaka to the second adhyāya of the third praghațtaka of Ānandatīrtha's Mahaitareyopanișadbhāssya.' Though the name 'Ānandatīrtha' is sometimes used to refer to Ānandagiri, it certainly refers here to Madhva, an assumption confirmed by the use of the word praghațtaka, which is not common in the Advaita tradition. The same confusion is made again by Keith in his 1909 book, where he maintains that the commentator on Śankara and the dualist Vaiṣnava thinker both known by the name 'Ânandatīrtha' are one and the same person (Keith 1909, 11-12). On this confusion, see inter alia the remarks by B.N.K. Sharma $(2000,168-169$, n. 3). To go back to the Bodleian manuscript, the colophon quoted in the catalogue speaks of a commentary (vivaraṇa) on 'the Bhāṣya [...] composed by the Revered Master Ānandatīrtha Bhagavatpāda' (śrīmadānaṃdatīrthabhagavatpādācāryaviracita[...]bhāṣya), which excludes any relation to Śañkara. The authors of the catalogue might have been misled by the fact that the same bundle contains commentaries by Śankara on two other ancient Upanișads $\left(\right.$ Kena $^{\circ}$ and Chāndogy ${ }^{\circ}$ ).

57 It is nevertheless remarkable (though, of course, not necessarily significant) that Ānandagiri's gloss on Śankara's AiUBh-S starts without a mangala-verse. The only similar case I know of among Ānandagiri's Śaṅkaran commentaries is his gloss on Śan̉kara's Praśnopaniṣadbhāṣya, which directly starts with a prose explanation. All his other sub-commentaries start with a mangala: that on BĀU has four verses, those on ChU and MāU two verses, while those on İsāu, $\mathrm{KeU}, \mathrm{KāU}, \mathrm{MuU}$ and TaiU have only one auspicious verse.

58 If we rely on catalogues and what has been discovered so far, the ratio between manuscripts transmitting the 'longer' and 'shorter' versions of AiUBh is approximately from one to ten.

59 We may imagine, for instance, that a commentary on the Ätmașațka alone would better serve the needs of a popular or 'ecumenical' diffusion of Advaita doctrines, while a more extensive commentary on the Āranyaka would be more suited for scholars specifically devoted to the study of the Vedas, or specialized in the recitation and interpretation of the Rgveda. 
piece of early medieval exegesis, but also better to understand the historical vicissitudes that lie behind this remarkable divergence in the way the Sankaran Advaita tradition dealt with the Aitareya-corpus.

\section{A preliminary survey of available editions and manuscripts}

Previous scholarship on AiUBh-L, which generally ignores the existence of two editions of the text, ${ }^{60}$ knows mainly of two manuscripts of the work, for which I will use the sigla $\mathbf{O}$ (Oxford, Bodleian Library, Mill Collection No. 120) and $\mathbf{L}$ (London, Whish Collection No. 164). ${ }^{61}$ Manuscript 0, a paper Devanāgarī manuscript (40 fols), undated but maybe produced in the $18^{\text {th }}$ century, is briefly described by Keith \& Winternitz (Bodleian No. 1014.1 - p. 79); ${ }^{62}$ it contains Śańkara's Bhāşya on AiĀ 2.1-3 and a fragment of his commentary on $A \mathrm{i} \overline{\mathrm{A}}$ 2.4; according to the authors of the catalogue, it is 'inaccurate and carelessly written.' Manuscript $\mathbf{L}$ is described in more detail by Winternitz (Asiatic Society No. 158 - pp. 216-217); ${ }^{63}$ it is in Malayalam script (150 fols), possibly copied in the $17^{\text {th }}$ century, and contains the whole of Śankara's commentary on AiĀ 2-3 with the exception of the beginning of 2.1 (2 folios are missing at the start of the bundle). This is the manuscript examined in 1930 by S.K. Belvalkar, who reproduces a limited number of passages and adds a few elements of description (pp. 244-245). This document was already 'in very bad condition' (Winternitz), 'much damaged' (Keith) or at least 'somewhat damaged' (Belvalkar) in the beginning of the last century. To this we must add one more recent Devanāgarī copy ( 69 fols) kept in Berlin (= B), unknown to Keith but pointed out by Belvalkar $(1930,246)$ following its brief description by A. Weber (Verzeichniss No. 90 - p. 21). According to the latter's record, it contains a complete commentary by Śankara on AiĀ 2-3, but this information is judged 'doubtful' by Belvalkar (1930, 246), who therefore considers that 'there is extant only one complete manuscript of [the] commentary by Śañkarācārya on Aitareya Āraṇyaka II and III,' namely L.

60 The only exceptions I know of are the brief reference to the Dharmakośa-reprint by S. Subrahmanya Shastri (discussed above, Section 1), and of course, Laxmanshastri Joshi's work itself, alone in acknowledging the existence of the 1884 Benares lithograph.

61 I have not been able to consult directly these two manuscripts so far, nor the Berlin copy mentioned below. This paragraph is thus entirely based on catalogues and secondary literature.

62 It is also mentioned by Keith $(1909,5)$ and Belvalkar $(1930,245)$, who do not add any particular information.

63 See also Keith 1909, 8. 
In addition to these three manuscripts, we now have at our disposal a fairly considerable number of other sources, including two editions of the text $\left(\mathbf{E d}^{\mathbf{1}}\right.$ and $\mathbf{E d}^{2}$ ) - the second a mere reprint of the first - and five newly identified manuscripts, here labelled C (Cambridge, UL Add. 2092), $\mathbf{C}^{\mathbf{M}}$ (Cambridge, UL Or. 2400), M (Chennai, GOML D 331 / SD 183), ${ }^{64} \mathbf{T}$ (Trivandrum, ORIML No. 6312) and V (Thrissur, Vadakke Madham Brahmaswam, uncatalogued). Adding these documents to those discussed by our predecessors, available sources can be roughly divided into two groups: a 'Northern' group possibly centred on Benares, including paper Devanāgarī manuscripts, the 1884 lithograph and its reprint $\left(\mathbf{E d}^{\mathbf{1}}, \mathbf{E d} \mathbf{d}^{\mathbf{2}}, \mathbf{C}\right.$, possibly $\mathbf{O}$ and B), and a 'Southern' group composed exclusively of palm-leaf manuscripts written in various South Indian scripts $\left(\mathbf{L}, \mathbf{C}^{\mathbf{M}}, \mathbf{M}, \mathbf{T}\right.$ and $\left.\mathbf{V}\right)$.

The first edition of the text $\left(\mathbf{E d}^{\mathbf{1}}\right)$ is in itself a remarkable document, that somewhat blurs the frontier between 'manuscript' and 'printed edition.' The only reason why I use the latter term is because the lithography-technique by which it was produced (named silākșara, 'stone-letters' in the colophon) allows (in theory, at least) the existence of several rigorously identical copies, even though in the present case only one could be located. ${ }^{65}$ The presentation of the book is otherwise exactly similar to that of a Northern paper pothi, with initial invocation (śri ganeśāya namah fol. 1r, 1. 1), rubrics and a colophon in Sanskrit and Hindī. It is in scriptio continua with the root-text (mūlagrantha) in the middle of the page, surrounded by Śankara's commentary artificially divided into two halves. For the section of the work reproducing also Ânandagiri's sub-commentary, the page is sometimes divided into five parts, with the root-text (mūlagrantha) in the centre, encircled by the commentary and sub-commentary, each split into two halves written in letters of decreasing size. ${ }^{66}$ The book is arranged in 70 folios written on both sides, continuously numbered on the verso (1-70). The recto of the first folio bears the 'title' atha pūrvottarārunabhāṣyasahitam sațikam aitareyopanișadbhāṣyam prārabhyate. Sections (khaṇa) within each adhyāya are numbered in the mūla-part and marked in the gloss by a brief rubric (iti prathamah khandah, etc.). Rubrics are found at the end of each adhyāya both in the mūla and the Bhāṣya (see above, Section 1). The book is

64 This manuscript had already been described in vol. 1.3 of the Descriptive Catalogue published by the GOML in 1905 (MD 1.3), but this description has apparently remained unnoticed.

65 See above $n .7$.

66 The text of Ānandagiri's gloss starts on fol. 22v12. It is graphically undistinguishable from the preceding Bhāsya, and immediately follows the final rubric of the third adhyāya (iti śrimacchaṃkarabhagavatpādakrtt[au] [...] tṛtīyo 'dhyāyah). The text of the Bhāșya continues in the centre of the same page (1. 8) with the initial rubric athaitareyașațkabhāṣyaprārambhah, 'Here begins the Bhāssya on the Aitareya-hexade.' The 'five-fold' layout is found on fols 31r-58v. 
concluded by an elaborate colophon, including the following Sanskrit stanza (fol. 70v16):

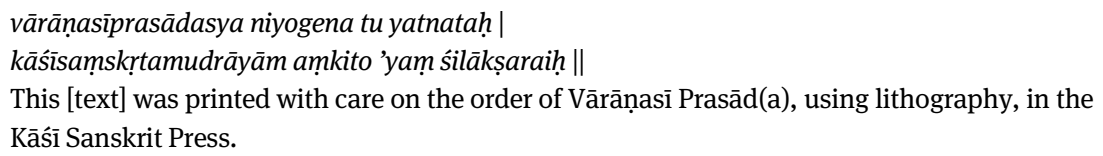

The Hindī colophon that follows (1. 16-17) confirms the name of the person who ordered the copy, Vārāṇasī Prasād(a), and also indicates the place where the book can be bought, the shop of a certain Pratāp Singh (pratāpasiṃha jī ke dukān) situated in Caurī Galī in Kāŝî (= Benares); it gives the date of printing as 1941 Vikrama (= $1884 \mathrm{CE}$ ). The second edition of the Bhāssya $\left(\mathbf{E d}^{2}\right)$, as part as of vol. 2.2 of Laxmanshastri Joshi's Dharmakośa (Upaniṣatkāṇda), merely reproduces the text of the first in a more 'edited' form, and does not constitute an independent source. It is mostly aimed at making the text accessible to a wide audience of scholars, 'as it has become difficult to access in manuscript or print' (asya durlabhatvāl likhitasya mudritasya $v \bar{a}) .{ }^{67}$ In accordance with the encyclopaedic mind that pervades the enterprise of the Dharmakośa, Śankkara's text is printed there along with Madhva's commentary, a welcome initiative that greatly facilitates comparison between the two major Bhāssyas on the 'longer’ Upanișad.

The first Cambridge manuscript (C) is also quite exceptional. Probably produced in a Jain scriptorium, it is dated 1650 Vikrama (=1593-94 CE), which makes it presumably the oldest surviving manuscript of the text, and no doubt one of the most valuable. Being a manuscript of Sankara's text alone, which it transmits in its entirety, it does not present the same confusion in rubrics and layout as Ed ${ }^{1}$. Thus, although both documents were produced in Benares, and even though chronology allows it, ${ }^{68}$ I find it unlikely that this manuscript served as the basis for the editio princeps. It is in excellent state of conservation, and the text is copied in a clear writing with relatively few scribal errors. A detailed description of the manuscript is now available online, which I will not reproduce here. ${ }^{69}$

If we now turn to our second group of sources, we see that they testify to a large diffusion of the text in the far South in the last centuries, spanning from the Śankkaran institutions of central Kerala to Andhra Pradesh, through Tamil-speaking

67 Laxmanshastri Joshi's note on p. 525 of his edition.

68 The manuscript was bought in Benares by Cecil Bendall for the Cambridge University Library in 1885 , thus possibly the year after $\mathrm{Ed}^{1}$ was produced in the same city.

69 See above n. 13. 
regions where Grantha script is used. The GOML Manuscript (M) has been described in some detail in $M D 1.3$ under No. 331 (pp. 315-317); it is written on palm leaf in Telugu script (58 fols), and contains Śańkara's complete commentary on AiĀ $2 .{ }^{70}$ It starts directly with the beginning of the 'longer' Bhassya, only preceded by a brief invocation (om). For the seventh adhyāya, which has not been commented on by Śankkara, the later commentary by Sāyaṇa has been tacitly introduced, following what seems to be a well-spread practice. ${ }^{71}$ The manuscript is complete, ending with what appears to be a date, which I have unfortunately been unable to decipher so far. In any case, it bears no sign that it ever contained a commentary on the third arranyaka. ${ }^{72}$ The Cambridge palm-leaf manuscript of AiUBh-L $\left(\mathbf{C}^{\mathrm{M}}\right)$, on the other hand, transmits Śankara's full commentary on AiĀ 2-3. Written on palm leaf in Malayalam script (150 fols), it is the work of a man named Govinda, otherwise unknown, and appears to have been copied in the $19^{\text {th }}$ or early $20^{\text {th }}$ century. A detailed description of the manuscript has been made by Elisa Ganser and myself, which is now available online. ${ }^{73}$ The last two manuscripts ( $\mathbf{T}$ and $\mathbf{V}$ ) have been identified only recently, and deserve a few more words.

Manuscript T is listed under No. 2912 in the first volume (A-Na) of the Trivandrum Alphabetical Index (p. 115), under the title Aitareyopanișadbhāṣyam by Śañkarācārya. The information provided by the catalogue, however, does not allow to differentiate it from a group of three manuscripts of AiUBh-S listed just above (Nos 2909-2911), and to identify it as a copy of the 'longer' Bhāșya; in particular, the given extent of the bundle ( 550 granthas) is clearly erroneous, and was probably copied from the preceding line. The identification of the manuscript was only possible through the inspection of the whole group of Bhässyas, a time-consuming procedure, but likely to bear fruit in other Indian libraries as well. The manuscript is on palm leaf, written in Grantha script (53 fols recently numbered on each page from 1 to 106; the original numeration is not readable on my copy of the manuscript), and transmits the complete text of Śankara's commentary on AiĀ 2-3. The text of the 'longer' Bhāssya begins directly on the top of the first folio, after a brief auspicious invocation (om śrīganeśāya namaḥ), and ends on p. 106 with the usual

70 The indication, found in the catalogue, that the manuscript contains 115 pages applies to the whole bundle, which also contains other Vedāntic texts. The leaves in that bundle have been numbered in modern times using Arabic numerals from 1 to 114 (no number on the last folio). Following this numeration, AiUBh-L starts on the top of fol. $55 \mathrm{r}$ and ends on the bottom of fol. 112r (the verso is blank). The folios containing Sankara's text are numbered from 1 to 58, using Telugu numerals.

71 The Benares lithograph, for instance, also introduces Sāyaṇa's commentary at that point.

72 I thank S.L.P. Anjaneya Sarma for his assistance while examining this manuscript.

73 See above n. 14. 
rubric marking the end of the 'Samhitopanișadvivarana' ${ }^{74}$ The bundle is still in relatively good shape, but many folios are damaged or worm-eaten, a situation that calls for urgent measures of conservation. ${ }^{75}$

Manuscript $\mathbf{V}$, on the contrary, is in a perfect state of preservation, and also has the complete 'longer' commentary by Śankara. It is kept in the library of the main hall (locally known as the 'Auditorium') of the Vadakke Madham Brahmaswam in Thrissur (Central Kerala), where it was kindly made available to me for consultation and photograph in July, 2016. The Vadakke ('Northern') Madham is a well-known Keralan institution devoted to the teaching of the Vedas, and is also one of the three remaining 'monasteries' (Sk. mațha, Mal. Madham) of the Thrissur Sannkaran tradition, together with the neighbouring Thekke and Naduvil Madhams. Its library gathers manuscripts that once belonged to all four Thrissur Madhams, and may contain today around 800 bundles of palm leaves. ${ }^{76}$ The library does not have a proper 'catalogue' so far, but several hand-lists have been produced in the last century (some of them have been used in the compilation of the NCC), and a new list has recently been started by students of the University of Kalady. ${ }^{77}$ The copy of Śankkara's 'longer' Bhāṣya could be identified with the help of this list, where it is found under No. 119 under the title 'Balavṛca Brāhmaṇopaniṣadvivaraṇam' by 'Śankkaran'. The manuscript is on palm leaf, in Malayalam script (166 fols, preceded by a blank folio and followed by a stray leaf), and was probably copied in the $19^{\text {th }}$ or early $20^{\text {th }}$ century. In that, and in many other aspects, it is very similar to $\mathbf{C}^{\mathrm{M}}$, the Keralan manuscript of AiUBh-L kept in Cambridge. A few pages are left blank (fols $79 \mathrm{v}, 148 \mathrm{v}, 152 \mathrm{v}$, as well as the verso of fols 159-161), but this does not correspond to divisions in the text itself, and may rather reflect peculiarities of the manuscript from which $\mathbf{V}$ was copied. The text starts directly on the top of fol. 1r, after a brief invocation (hariḥ, śrìganapataye namah, mahāganapataye namaḥ, oṃ), and ends

74 See fol. 53v2-3 : iti śrīgovindabhagavatpūjyapādaśișyasya paramahaṃsaparivrājakācāryasya śriśánkarabhagavatạ̣ kṛtau saṃhitopaniṣadvivaraṇaṃ samāptam.

75 During my visit to Trivandrum in July, 2016, I was allowed to see the manuscript, but not to take photographs. The present description is therefore based on my notes, as well as on the black and white photocopies provided by the library in the following weeks. Unfortunately, only a few folios of the bundle are actually legible with the help of these photocopies. I hope the authorities of the ORIML will allow the EFEO to take digital pictures of the document in the near future, as this would allow both a better conservation of the material (avoiding further damage by operations of photocopying) and a greater accessibility to scholars.

76 The manuscripts are currently piled up in two large cupboards, which are literally packed with bundles, so that it is extremely difficult to estimate their exact number.

77 I thank Mr Murali Krishnan, one of the compilers of the new list, as well as the authorities of the Brahmaswam Madham, for granting me access to two versions of the list, as well as to other important documents related to this collection. 
on the recto of fol. 166 with the final rubric concluding the commentary (vivarana) on the Samhitopanișad, followed by a brief homage to the gurus. ${ }^{78}$

The results of this preliminary survey are summarised in the following chart, which lists, for the various sources, adhyāyas which are transmitted (yellow), incompletely transmitted (light grey) or not transmitted (dark grey); the thick line differentiates sources that were known to Keith and Belvalkar (upper half) from those that were discovered more recently (lower half):

\begin{tabular}{l|l|l|l|l|l|l|l|l}
\hline & 2.1 & 2.2 & 2.3 & 2.4 & 2.5 & 2.6 & 3.1 & 3.2 \\
\hline $\begin{array}{l}\text { 'Vulgate' edi- } \\
\text { tions of AiUBh }\end{array}$ & & & & & & & & \\
\hline $\mathrm{O}$ & & & & & & & & \\
\hline $\mathrm{L}$ & & & & & & & & \\
\hline $\mathrm{B}$ & & & & & & & & \\
\hline \hline $\mathrm{Ed}^{1}$ & & & & & & & & \\
\hline $\mathrm{Ed}^{2}$ & & & & & & & & \\
\hline $\mathrm{C}$ & & & & & & & & \\
\hline $\mathrm{C}$ & & & & & & & & \\
\hline $\mathrm{M}$ & & & & & & & & \\
\hline $\mathrm{T}$ & & & & & & & & \\
\hline $\mathrm{V}$ & & & & & & & & \\
\hline
\end{tabular}

In view of this, it is clear that Belvalkar's statement that 'a satisfactory edition of the work cannot be issued unless more manuscript material becomes available' $(1930,246)$ does not really hold anymore. It is thus high time for researchers and scholars of Vedānta to make this valuable work accessible again to its readers in an edition worth the name, and to investigate what seems to have been an unexpected turn of events in the history of the non-dualistic tradition of commentary on the Aitareyopanișad. ${ }^{79}$

78 See fol. 166r5-6: iti śrīgovindabhagavatpūjyapādaśișyasya paramahaṃsaparivrājakācāryaśaṃkarabhagavataḥ kṛtau saṃhitopaniṣadvivaraṇaṃ samāptam, hariḥ, śrīgurubhyo namaḥ. 79 This article was already in proof stage when I came to know of one more edition of Śankara's commentary on AiĀ 2.1-3, published in 2008 by the Adhyatma Prakasha Karyalaya in Holenarasipur (ed. M.R. Keśavah Avadhānī - I thank S.L.P. Anjaneya Sarma and Pt. Mani Dravid for drawing my attention to that edition). The book is in two parts, the first one comprising the text of AiUBh-L up to 2.3, the second reproducing the text of AiUBh-S as it is found in the Ānandāśrama 


\section{Table of sigla}

\subsection{Manuscripts of AiUBh-L}

B = Berlin, No. 90 in Weber's Verzeichniss.

C = Cambridge, UL No. Add. 2092.

$\mathrm{C}^{\mathrm{M}}=$ Cambridge, UL No. Or. 2400.

L = London, Whish Collection No. 164 .

M = Madras (Chennai), GOML No. D-331 /SD 183.

$\mathbf{0}=$ Oxford, Bodleian Library, Mill Collection No. 120 .

T = Trivandrum, ORIML No. 6312 .

$\mathbf{V}=$ Manuscript of AiUBh-L kept in the Vadakke Madham Brahmaswam, Thrissur.

\subsection{Other sigla}

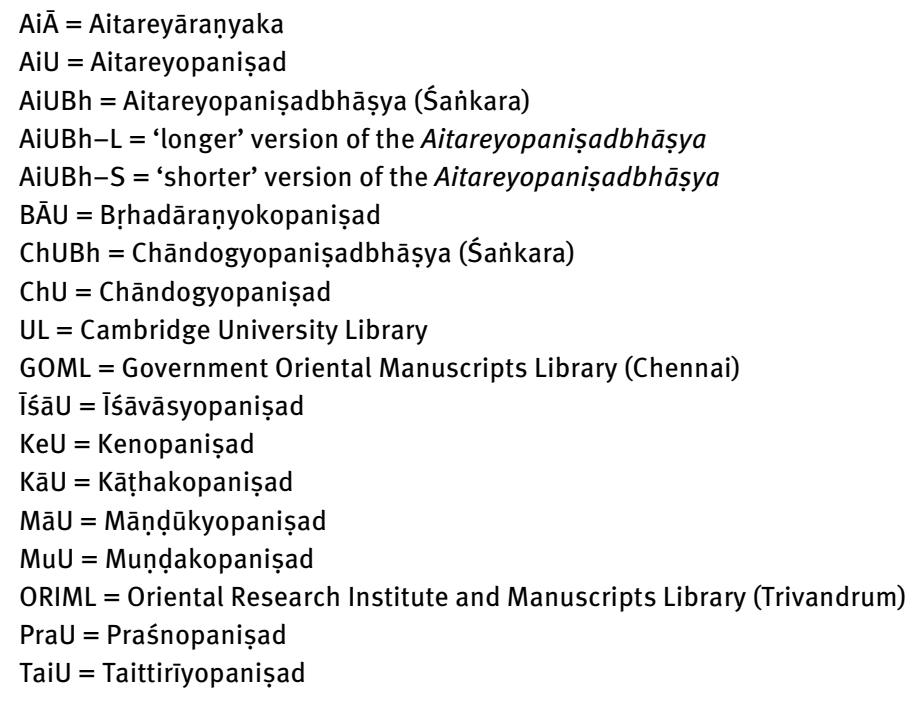

edition, with emendations and notes. The manuscript used as a basis for the first part is described in the English introduction in very generic terms as 'a hand written manuscript titled "Sri Shankaracharya Krita Bhashyam,” comprising a Bhashya on all the six chapters' (p. iii). More research will be needed to determine if this manuscript corresponds or not to any of those described in this section. In any case, the editor does not show any awareness of further manuscripts or earlier editions of Śaṅkara's commentary on AiĀ 2.1-3, nor does he seem to know the existence of his commentary on $\mathrm{AiĀ} 3$. 


\section{References}

\section{Primary sources}

\section{Main editions of the 'shorter' Aitareyopaniṣadbhāșya}

The Taittirīya and Aitareya Upanishads with the Commentary of Śankara Āchārya, and the gloss of Ānanda Giri, and the Swetāswatara Upanishad with the Commentary of Śankara $\bar{A} c h a \bar{r} y a$, E. Röer (ed.), Calcutta, Baptist Mission Press, 1850 (Bibliotheca Indica 6). Aitareyopaniṣat sațīkaśānkarabhāṣyopetā tathā ca vidyāraṇyakrtā aitareyopaniṣaddīpikā, edited by the Ānandāśrama paṇ ḍits, Pune (Puṇyapattana), Ānandāśramamudraṇālaya, 1889 (Ānandāśramasaṃskṛtagranthāvalị̣ 11).

\section{Editions of the 'longer’ Aitareyopaniṣadbhāṣya}

$\mathbf{E d}^{1}=$ [The long Aitareya Upanișad, or adhyāyas 2 and 3 of the Aitareya Āraṇyaka, also called Bahvṛca or Mahaitareya Upanișad. With the commentaries of Śamkara Ācārya and Ānandagiri. Edited by Babu Vārāṇasī Prasāda. Benares, 1884]. Copy kept in the Harvard University Library - Widener Library (Ind L 3117.56 F). ${ }^{80}$

$\mathbf{E d}^{2}=$ Dharmakośa - Upaniṣațkāṇ̣a vol. II, Part II, ed. Laxmanshastri Joshi, Wai (Satara), Prājña Pāṭhaśālā Maṇḍala, 1949 (the text of the Bhāṣya is found on pp. 525-626).

\section{Other Sanskrit sources}

Aștādaśopaniṣadaḥ ('Eighteen Principal Upanișads'), vol. 1, V.P. Limaye \& R.D. Vadekar (eds), Poona, Vaidika Saṃśodhana Maṇạala, 1958 (Gandhi Memorial Edition).

Upanișadbhāṣyam, 3 vol., ed. S. Subrahmaṇya Shastri, Benares (Varanasi) / Mount Abu, Mahesh Research Institute (Advaita Grantha Ratna Manjusha 21, 24 \& 28), 1982 (vol. 2), $1986^{1}$ (vol. 3), $2004^{2}$ (vol. 1; revised by Mani Dravid).

Vol. 1: Bhāṣyas on İśāU, KeU, KāU, MuU, PraU, MāU, TaiU and AiU.

Vol. 2: Bhāṣya on ChU.

Vol. 3: Bhāṣya on BĀU.

Aitareyāranyaka (with Sāyaṇa's commentary) = Bahvṛcabrāhmaṇāntargatam Aitareyāraṇyakam śrīmatsāyaṇācāryaviracitabhāṣyasametam, $2^{\text {nd }}$ edition (without editor's name), Pune, Ānandāśrama, 1992 (Ānandāśramasaṃskṛtagranthāvalị̣ 38).

Aitareyopanișat with four commentaries (critical edition), M.A.S. Rajan \& M.A. Lakshmitatacharyar (eds), Melkote, Academy of Sanskrit Research, 1997 (Academy of Sanskrit Research Series 33).

80 As the edition does not have a title page, I reproduce here, for easy reference, the information found in the Harvard library catalogue. 
Taittirīya-Aitareya-Chāndogyopaniṣadbhāṣyam Śrīrañgarāmānujamuniviracitam (no editor's name), Madras, $1973^{2}$ (first edition: Tirupati, 1951).

Daśopanișad-s, with the Commentary of Śrī Upanișadbrahmayogin, Part 1 (Īśā to Aitareya), edited by the pandits of the Adyar Library under the supervision of C. Kunhan Raja, revised by A. A. Ramanathan, Madras, $1984^{2}$ (first, unrevised edition: Madras, 1935).

Brahmasūtrabhāṣya = Brahmasūtraśāṅkarabhāṣyam, Anantakrishna Shastri \& Vasudeva Laxman Shastri Pansikar (eds), Benares (Varanasi), Krishnadas Academy, 2000 (Krishnadas Sanskrit Series 25).

\section{Secondary sources}

Belvalkar, S.K. (1930), 'An authentic but unpublished work of Śañkarācārya', in Journal of the Bombay Branch of the Royal Asiatic Society (New Series), 6: 241-246.

Böhtlingk, Otto (1998), Pānini's Grammatik. Delhi: Motilal Banarsidass (Indian reprint; first edition: Leipzig, 1887).

Cohen, Signe (2008), Text and Authority in the Older Upanișads (Brill's Indological Library 30), Leiden-Boston: Brill.

Hacker, Paul (1995), 'Śańkarācārya and Śan̉karabhagavatpāda: Preliminary Remarks concerning the Authorship Problem', in W. Halbfass (ed.), Philology and Confrontation. Paul Hacker on Traditional and Modern Vedānta, Albany: State University of New York Press, 41-56.

Harimoto, Kengo (2014), God, Reason, and Yoga. A Critical Edition and Translation of the Commentary Ascribed to Śan்kara on Pātañjalayogaśāstra 1.23-28 (Indian and Tibetan Studies 1), Hamburg: Department of Indian and Tibetan Studies, Universität Hamburg.

Keith, Arthur Berriedale (1909), The Aitareya Āranyaka, edited from the Manuscripts in the India Office and the Library of the Royal Asiatic Society with Introduction, Translation, Notes, Indexes and an Appendix containing the portion hitherto unpublished of the Sānikhāyana Āranyaka, Oxford, Clarendon Press (reprint: Delhi, Eastern Book Linkers, 2005).

Mayeda, Sengaku (1968), 'On Śańkara's authorship of the Kenopanișadbhāșya', in IndoIranian Journal, 10.1: 33-55.

Müller, Friedrich Max (1859), A History of Ancient Sanskrit Literature so far as it illustrates the Primitive Religion of the Brahmans, London: Williams \& Norgate.

Müller, Friedrich Max (1879), 'Introduction to the Upanishads'; pp. Ivii-ci in The Upanishads, (Sacred Books of the East 1), Oxford: Clarendon Press.

Narayanacharya, K.S. (1997), 'Introduction'; pp. i-xx in Aitareyopanișat with four commentaries (see under that title).

Rapson, Edward J. (1910), Review of Keith 1909, in Journal of the Royal Asiatic Society of Great Britain and Ireland (July 1910): 892-899.

Renou, Louis (1947), Les écoles védiques et la formation du Veda (Cahiers de la Société Asiatique 9), Paris: Imprimerie Nationale.

Schneider, Ulrich (1963), 'Die Komposition der Aitareya-Upanișad'; in Indo-Iranian Journal, 7: 58-69.

Sharma, B.N.K. (2000), History of the Dvaita School of Vedānta and its Literature, from the earliest beginnings to our times, Delhi: Motilal Banarsidass ( $3^{\text {rd }}$ revised edition; $1^{\text {st }}$ edition: Bombay, 1961). 


\section{Catalogues of manuscripts}

Alphabetical Index (Trivandrum) = Alphabetical Index of the Sanskrit Manuscripts in the University Manuscripts Library, Trivandrum, vol. 1 (A to NA), edited and published by Suranad Kunjan Pillai, Trivandrum, The Alliance Printing Works, 1957.

Keith \& Winternitz, Bodleian = Catalogue of Sanskrit Manuscripts in the Bodleian Library - vol. II, begun by Moriz Winternitz, continued and completed by Arthur Berriedale Keith, Oxford, Clarendon Press, 1905.

MD 1.3 = A Descriptive Catalogue of the Sanskrit Manuscripts in the Government Oriental Manuscripts Library, Madras by M. Seshagiri Sastri and M. Rangacharya, vol. 1 (Vedic Literature), part 3. Madras, Government Press, 1905.

NCC $3=$ New Catalogus Catalogorum. An Alphabetical Register of Sanskrit and Allied Works and Authors. Volume three. V. Raghavan and K. Kunjunni Raja (eds). Madras, University of Madras, 1967 (Madras University Sanskrit Series 28).

Weber, Verzeichniss = Verzeichniss der Sanskrit-Handschriften, von Albrecht Friedrich Weber, Berlin, Verlag der Nicolai'schen Buchhandlung, 1853 (Die Handschriften-Verzeichnisse der Königlichen Bibliothek 1).

Winternitz, Asiatic Society = A Catalogue of South Indian Sanskrit Manuscripts (especially those of the Whish Collection) belonging to the Royal Asiatic Society of Great Britain and Ireland, compiled by M. Winternitz with an appendix by F.W. Thomas, London, The Royal Asiatic Society, 1902. 